\section{Agreement nears on protection of the Earth's ozone layer}

Brussels

KEY actors in the continuing drama surrounding an international protocol to protect the Earth's ozone layer by regulating chlorofluorocarbons (CFCs) are meeting in Brussels this week for final discussions and negotiations before governments are asked to sign the far-reaching agreement in September.

The meeting, an informal gathering of representatives of signatories of the Vienna Convention for the Protection of the Ozone Layer and its chairman, United Nations Environment Programme director Mostafa Tolba, has been aimed at settling issues left outstanding after the last round of negotiations at Geneva in April. But instead of the entourages of advisers, government representatives, non-government organizations, scientists and economists familiar at previous Vienna Convention meetings, this week's discussions have involved only the heads of delegations of some signatories, which marks a shift of the negotiations from the technical level to the political.

One of the crucial issues for this week's discussions has been the size of the reduction in global production and consumption of CFCs, which are used as aerosol propellants, foam-blowing agents, refrigerants and solvents. The draft agreement in April called for a freeze of CFCs 11,12 and 113 at the 1986 level, a 20 per cent cutback two years later and a second stage reduction of a further 30 per cent, either after six or eight years.

At the start of this week's meeting, there were signs of some backtracking on that position, especially by the European Community. A commission representative said in Brussels last week that a simple 20 per cent reduction "represents what is necessary and achievable in the short term". While the official US position is that CFCs should eventually be eliminated, that position is opposed by officials in the Interior Department and the Commerce Department, who last week put their arguments to President Reagan.

Negotiations in Brussels this week have also dealt with the question of trade in $\mathrm{CFCs}$, including provisions for regulating and monitoring trade between producer and non-producer countries.

The scientific evidence that first led to concern about CFCs is being discussed by an international committee set up by the US National Aeronautics and Space Administration (NASA), the Ozone Trends Panel, which met last week. The panel and its working groups comprise more than 100 people concerned with all aspects of research into stratospheric ozone depletion, both total column and vertical profile, as well as the role of CFCs in ozone destruction. The panel is also reviewing satellite and ground-based ozone data, partly as a response to evidence submitted to the US Congress earlier this year by NASA scientist Don Heath which concluded, on the basis of satellite data, that global ozone depletion has been far more severe than originally

Members of the working group on the Antarctic ozone hole are awaiting the result of this year's Antarctic Ozone Expedition, expected to provide more information on whether the ozone hole is predicted.

\section{London}

AmBIтIOUs proposals were unveiled last week to widen access to higher education across the nations of the British Commonwealth by using new and wellestablished techniques of long-distance learning. The 'University of the Commonwealth for Co-operation in Distance Education' would use correspondence courses, tape recordings and video cassettes, and would seek access to electronic mail and communcations satellites to link universities with the aim that "any learner, anywhere in the Commonwealth, shall be able to study any distanceteaching programme available from any bona fide college or university in the Commonwealth".

The proposals come from a group of independent education experts set up by the Commonwealth secretary-general last October to report on the potential for Commonwealth cooperation in distance learning. The report, (Towards a Commonwealth of Learning, Commonwealth Secretariat, London, £6) says: "Students can, in principle, follow a course from an institution outside their country. Universities can share their teaching through satellites. Audiotapes, video cassettes and discs can be distributed like books." The programme would help colleges to reach new audiences and to widen the range and raise the quality of teaching on campus, and the university would be of particular value for would-be students remote from an educational institution, and for parttime students, the report says.

The proposed university would begin with a small nucleus of about 20 professional staff, building up to about 60 over five years, when it would be able to offer the equivalent of some 20 full degree caused by chemicals such as CFCs or is a dynamic process. New data, not yet published, are consistent with the chlorine hypothesis.

The panel will also study a decrease in global ozone in the early 1960 s to tell whether extra nitrogen produced by nuclear testing could have been responsible.

NASA scientist Dr Robert Watson, chairman of the Ozone Trends Panel, says its report has "become a monumental work" and is unlikely to be completed before the scheduled September meeting for the signing of an international protocol on CFCs. "But the politicians have enough to go on now", Watson notes. "Anything we find will only make the situation worse for CFCs, not better."

Kathy Johnston

\title{
University proposed to span British Commonwealth
}

courses. The operating budget for the first year is estimated at around $£ 2.4$ million, with an annual expenditure of $£ 5-6$ million for the first five years, increasing to $£ 8$ million thereafter. Teaching material would be built up from the best courses available from open unversities and distance-teaching universities throughout the Commonwealth.

The report suggests that where computer technology is required, "major multinational computer companies might well help with the funding of courses and the supply of computer hardware and software on favourable terms".

The subject areas of science, mathematics and technology are singled out as being particularly appropriate for international distance-learning, specifically mathematics and the physical sciences. The report acknowledges that many educational institutions with established distance-teaching techniques have hesitated to introduce science teaching, often because of the difficulty of arranging practical work. It points out, however, that open universities have successfully introduced home science kits and vacation laboratory work. Worldwide demand for applied scientists and technologists, particularly in electronics, information technology and computer studies, made this "one of the most promising areas for development of cooperation". The university would need a location where it could be "assured of government support and would have easy access to Commonwealth resources, with good communications facilities, and with an adequate infrastructure of services"

The proposals will be considered by Commonwealth education ministers later this month and by heads of government in October.

Simon Hadlington 